\title{
Assessment of Spring Chemistry Along the South Rim of Grand Canyon in Grand Canyon National Park, Arizona -A U.S. Geological Survey and National Park Service Partnership-
}

Spring flow from the south rim of Grand Canyon (fig. 1) is an important resource in Grand Canyon National Park (GCNP). Springs offer refuge to endemic and exotic terrestrial wildlife species and help maintain the riparian areas associated with this resource. Recent real estate development on the Coconino Plateau (fig. 1), a subregion of the Colorado Plateau south of Grand Canyon, has heightened the awareness of environmental groups, commercial developers, and resource managers to the importance of spring resources. Native Americans in the Grand Canyon region, such as the Havasupai Tribe, are concerned that ground-water pumpage may affect the spring resources. For Native Americans, springs are not only economically important but also culturally significant.

The U.S. Geological Survey (USGS) and GCNP began a cooperative program in 1999 under the auspices of the WaterQuality Monitoring and Assessment Partnership, a Clean Water Action Plan program (2002), shared between the USGS and the National Park Service (NPS). Nineteen springs have been sampled to date that issue from the Redwall and Muav Limestones along the south rim of Grand Canyon.

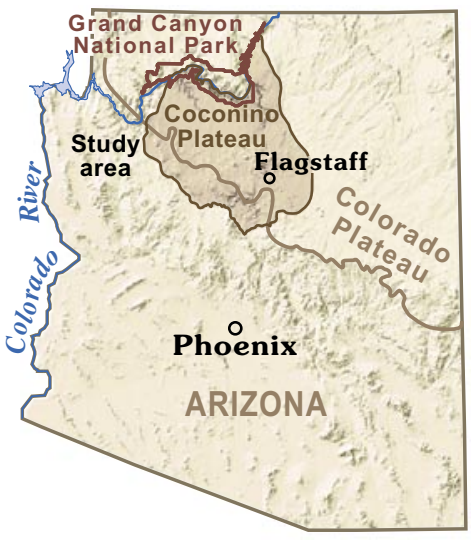

Figure 1. Location of the study area.

\section{Spring Resource Issues}

Tributary streams occupy 0.003 percent of the area of Grand Canyon; however, 36 percent of the total riparian flora exists within those confines (John Rihs, hydrologist, GCNP, written commun., 2002). Baseline, seasonal, and annual water-quality data from springs along the south rim and identification of spring sources are needed to address four issues identified by GCNP:

- The quality of water from springs and seeps can limit recreational use of the water.
- Changes in the quality, quantity, and sustainability of flow from springs can affect the long-term health of biological communities and riparian habitats associated with these areas.

- Climate variability can affect spring flow and thus the riparian habitats associated with these areas

- Ground-water pumpage from the Redwall and Muav Limestones south of Grand Canyon may affect spring flow.

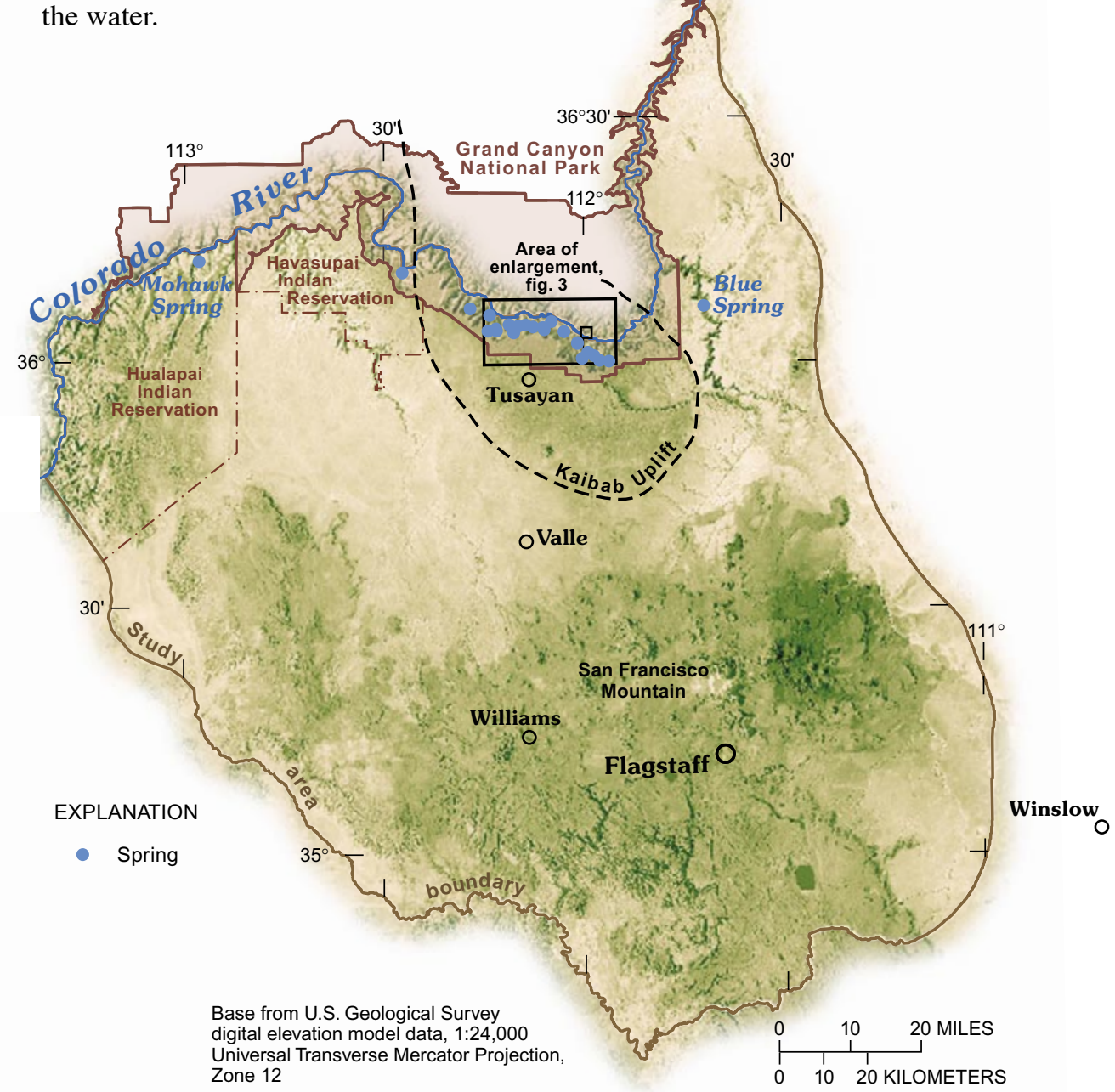


Population growth on the Coconino Plateau has raised concern about the potential demise of spring resources of Grand Canyon. Ground-water development near the communities of Valle and Tusayan, Arizona (fig. 1), has prompted GCNP to monitor flow from selected springs along the south rim of Grand Canyon. Variability in spring flow can indicate stresses caused by ground-water development in the basins, or indicate changes in the regional climate.

\section{Objectives of the Study}

The objectives of the study are to:

- Accurately locate and map significant springs issuing from the Redwall and the Muav Limestones.

- Describe the general water chemistry of springs.

- Verify the source of water discharging at springs and determine the approximate age of spring water.

-Measure spring-flow discharge.

In addition to data collection at springs, water samples are proposed to be collected from wells in Tusayan and Valle south of Grand Canyon. Wells in these communities tap the Redwall Limestone or Muav Limestone for water supply and are believed to lie in the path of ground-water flow to south rim springs. Analyses of water samples from these wells are critical for determining the sources and flow paths of water that discharges at springs along the south rim of Grand Canyon.

\section{Physical Setting}

The study area extends across the Coconino Plateau, an area of about $5,000 \mathrm{mi}^{2}$ in the southern part of the Colorado Plateau in northern Arizona (fig. 1), to allow collection of information on spring source areas and ground-water development. The Coconino Plateau extends from GCNP south to the Mogollon Rim, and from near Winslow northwest to the Hualapai Indian Reservation. Altitudes within the study area range from $12,500 \mathrm{ft}$ at San Francisco Mountain to 2,400 $\mathrm{ft}$ on the Colorado River near Grand Canyon. The greatest rainfall occurs during the southwestern monsoon from mid-June to early October. Snowfall on the Coconino Plateau can be significant at higher elevations and accounts for the greatest portion of the total precipitation in these areas. The climate of the Coconino Plateau changes with altitude. Above 7,000 ft, annual precipitation varies from $19.1 \mathrm{in}$. on the Kaibab uplift (fig. 1) to about 21 in. near Flagstaff (Sellers and others, 1986).
Along the Colorado River, the climate is continental and arid. Precipitation ranges from 5.9 in. at Lees Ferry (river mile 0) to 9.1 in. at Phantom Ranch (river mile 86; Sellers and others, 1986).

\section{Water-Bearing Units}

The water-bearing units from which springs along the south rim typically issue are limestones and sandstones of Paleozoic age (fig. 2). Water in the Redwall and Muav Limestones is the primary source of spring flow along the south rim of Grand Canyon owing to faults and fractures (Metzger, 1961; Huntoon, 1974). Below the Muav Limestone, the less permeable Bright Angel Shale acts as a physical barrier to downward movement of ground water from overlying rocks (Huntoon, 1974).

Seeps and springs also occur from the Cambrian Tapeats Sandstone, which underlies the BrightAngel Shale, and in the Pennsylvanian and Permian Supai Group and the Permian Coconino Sandstone that overlie the Redwall Limestone.

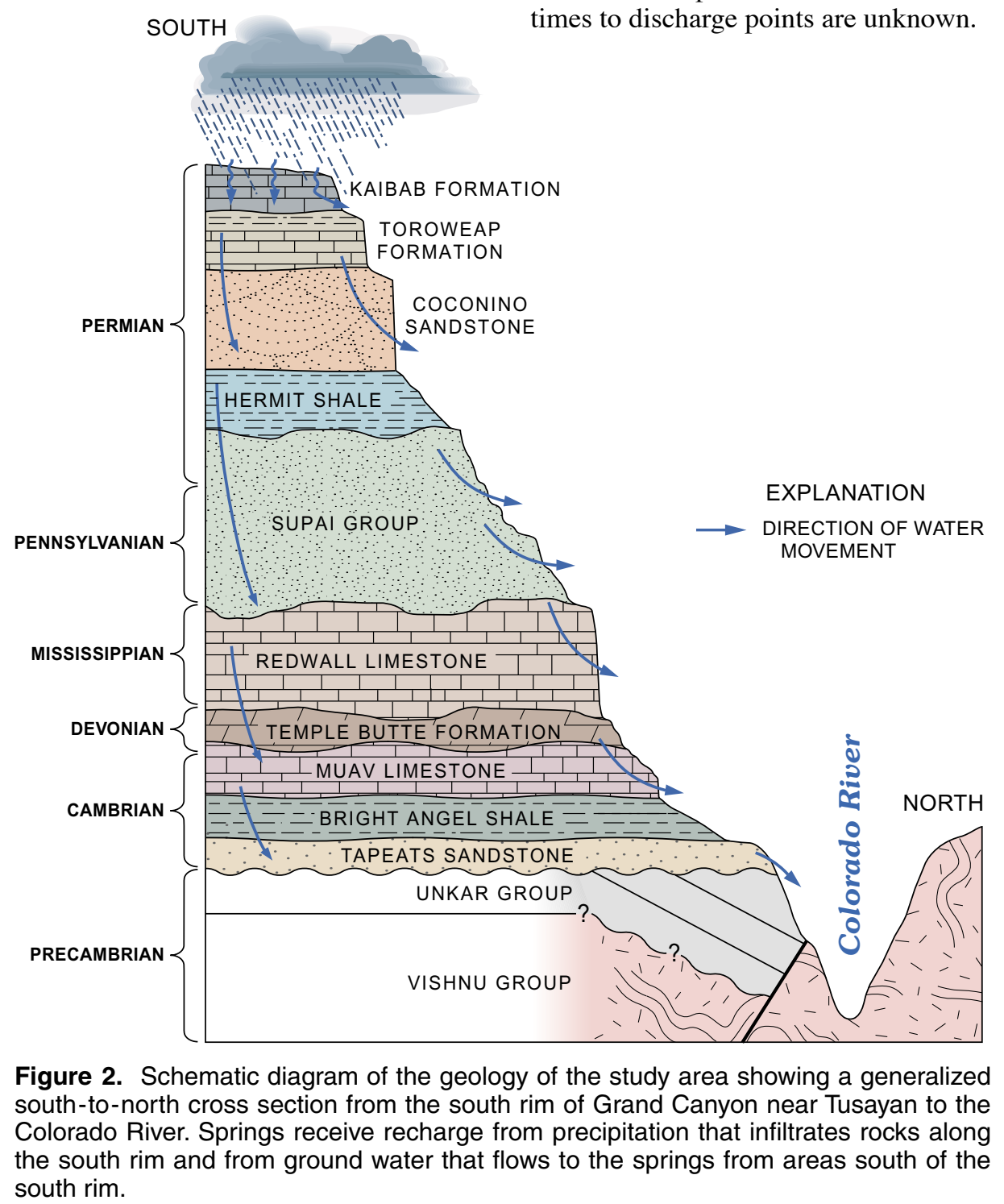

Figure 2. Schematic diagram of the geology of the study area showing a generalized south-to-north cross section from the south rim of Grand Canyon near Tusayan to the Colorado River. Springs receive recharge from precipitation that infiltrates rocks along the south rim and from ground water that flows to the springs from areas south of the south rim.

The hydrogeology of the deeply buried Redwall and Muav Limestones and the hydraulic connection of these units with the overlying Pennsylvanian and Permian rocks of the Coconino Plateau near Grand Canyon are poorly known.

The water-bearing units are recharged primarily by precipitation that infiltrates outcrops of volcanic rocks, the Kaibab Formation, and the Coconino Sandstone in the higher altitudes of the Coconino Plateau (Johnson and Sanderson, 1968). Faults and fractures, many widened by solution, create zones of secondary permeability that could be the primary controls of ground-water movement. Ground water in the south rim area and in the northern parts of the plateau generally flows toward the south rim and discharges at springs and seeps in Grand Canyon (fig. 2). Springs and seeps typically occur at geologic contacts where water-bearing rocks are underlain by less permeable rocks. Large springs in the canyon are associated with regional faults. Very little is known about the movement of ground water through the rocks of the plateau; therefore, travel times to discharge points are unknown. 


\section{Sampling Approach and Chemical Analyses}

Data have been collected from 19 springs since the program began in 1999 (table 1). Analyses of the stable isotopes of carbon $\left({ }^{13} \mathrm{C}\right.$ and $\left.{ }^{12} \mathrm{C}\right)$ are used to determine recharge areas. These isotopes are affected by photosynthesis and other biological and environmental factors (Drever, 1988). The ${ }^{13} \mathrm{C} /{ }^{12} \mathrm{C}$ value in water is dependent on the isotopic composition of carbon dioxide in the soil (rock) at the recharge area and on reactions between the water and carbonate minerals along the flow path (Lopes and Hoffmann, 1997). Strontium isotope data $\left({ }^{87} \mathrm{Sr}\right.$ and $\left.{ }^{86} \mathrm{Sr}\right)$ also help to identify flow paths. For example, water that receives recharge primarily through limestone has a heavier strontium composition (larger ${ }^{87} \mathrm{Sr} /{ }^{86} \mathrm{Sr}$ value) than water that receives recharge primarily through volcanic rocks. Data from the analyses of oxygen $\left({ }^{18} \mathrm{O}\right.$ and $\left.{ }^{16} \mathrm{O}\right)$ and hydrogen $\left({ }^{2} \mathrm{H}\right.$ and ${ }^{1} \mathrm{H}$ ) isotopes provide information about sources of recharge from rainfall or snowmelt and whether the recharge source has been affected by evaporation. Analyses of the radiogenic isotopes of carbon $\left({ }^{14} \mathrm{C}\right)$ and hydrogen $\left({ }^{3} \mathrm{H}\right.$, tritium $)$ are used to determine ground-water age, which can be used to infer travel times along ground-water flow paths.
Table 1. Springs sampled, field measurements, and analytes

\begin{tabular}{|c|c|}
\hline \multicolumn{2}{|c|}{$\begin{array}{l}\text { Springs sampled: Blue Spring, Red Canyon Spring, JT Spring, Miners Spring, Cottonwood Spring, } \\
\text { Grapevine East Spring, Grapevine Main Spring, Lonetree Spring, Sam Magee Spring, Burro Spring, } \\
\text { Pipe Spring, Pumphouse Spring, Horn Creek, Salt Creek Spring, Monument Spring, Hawaii Spring, } \\
\text { Hermit Spring, Boucher East Spring, Mohawk Spring }\end{array}$} \\
\hline Field measurements & Analytes \\
\hline $\mathrm{pH}$ and temperature & Major ions \\
\hline Specific conductance & Trace metals \\
\hline Dissolved oxygen & Rare earth elements \\
\hline Alkalinity & Nutrients \\
\hline Spring discharge & $\begin{array}{c}\text { Stable isotopes } \\
\text { (oxygen, hydrogen, carbon, and strontium) }\end{array}$ \\
\hline \multirow{2}{*}{ Elevation and location of spring outlet } & $\begin{array}{l}\text { Radiogenic isotopes } \\
\text { (tritium and carbon-14) }\end{array}$ \\
\hline & Radionuclides-gross alpha/beta \\
\hline
\end{tabular}

Carbon-14 has a half-life of 5,730 years, and tritium has a half-life of 12.3 years. Large amounts of both were released into the atmosphere during testing of nuclear weapons during the 1950s and 1960s (Fritz and Fontes, 1980). Baseline water chemistry determined from analyses of major ions and other constituents can allow future studies to measure changes in chemistry over time and potentially identify factors responsible for the changes. Concentrations of trace and rare earth elements also can potentially provide information useful for identifying recharge areas. Nutrient analysis provides information on the general water quality of the spring water.

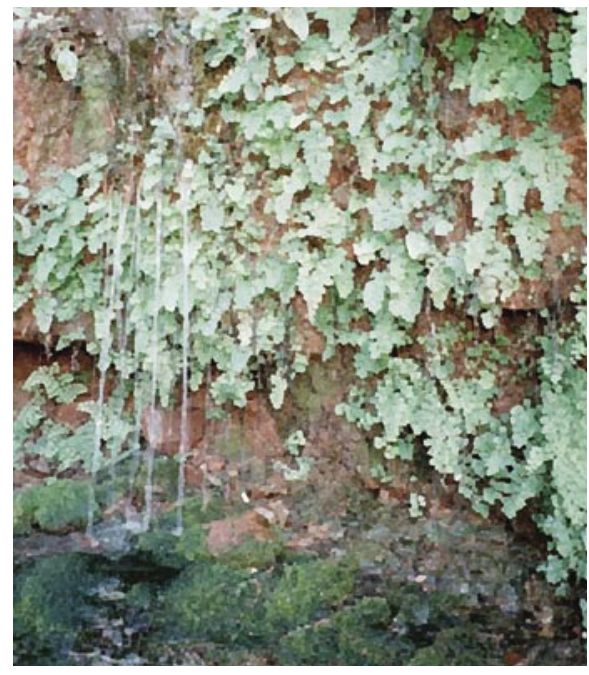

Monument Spring at source, first major canyon to the east of Hermit Creek

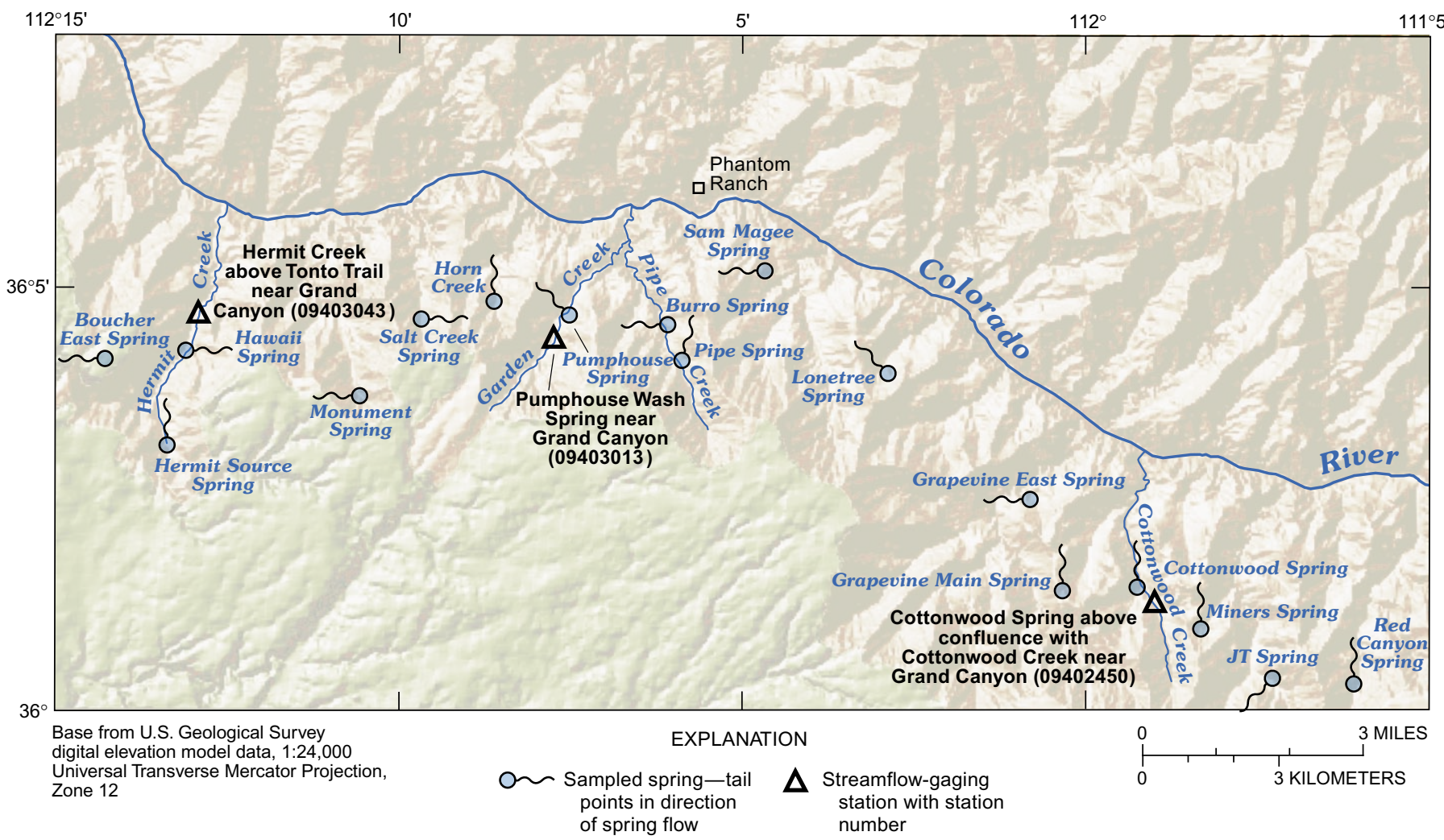

Figure 3. Sampled springs and streamflow-gaging stations on the south rim of Grand Canyon. 


\section{Long-Term Needs of GCNP}

GCNP has the responsibility of protecting the natural resources of Grand Canyon and depends on partnerships with government and private organizations to address resource issues. Long-term needs of GCNP require a knowledge base of the Redwall and Muav Limestones and other water-bearing units of the Colorado Plateau including the Coconino Sandstone and Supai Group, in order to properly manage and protect the seeps and springs of the park. To help achieve this need, GCNP has initiated several programs and is pursuing continued or expanded programs comprising monitoring and research components including the following:

A. Water-chemistry data collection, compilation, and evaluation. The collection and evaluation of water chemistry data will continue as part of the park's effort to identify the source of water to each spring and the geologic and water-quality characteristics of each spring. Future data collection will involve inventorying new springs, repeat sampling at selected sites to help determine seasonal variability, and collection of data from ground-water wells on the Coconino Plateau. Selected chemical constituents will be added to the analyses to refine the age estimates for spring waters. For example, ${ }^{36} \mathrm{Cl}$ and chlorofluorocarbons (CFCs) from selected sites could be analyzed to provide additional information in support of estimates based on ${ }^{14} \mathrm{C}$ and ${ }^{3} \mathrm{H}$ data.
Springs that issue from other stratigraphic units in the park that overlie and underlie the Redwall and Muav Limestones will be sampled to determine the hydrogeologic relations among the units.

B. Expand spring discharge monitoring. Continuous stage will be recorded and discharge will be measured on Cottonwood Creek, Pumphouse Wash, and Hermit Creek (fig. 3). Periodic measurements will be made at selected springs that are believed to issue from the Redwall-Muav Limestone aquifer. Additional spring-flow gages may be installed to increase monitoring coverage and to further document long-term changes in spring flow.

C. Develop and support geologic and geophysical framework. Gravity and aeromagnetic data are being used in the ongoing geologic surface mapping and geophysical evaluation. This data will provide information on the geologic structure that controls regional ground-water flow on the Coconino Plateau and spring discharge along the south rim of Grand Canyon.

D. Develop and support of biologic inventory, habitat mapping, and habitat modeling. Grand Canyon springs and seeps often support rare, endangered, endemic, and other species of special concern. Preserving and managing these areas cannot be done without baseline biological and riparian information. The park and its cooperators continue to collect baseline data on ecosystem health that are necessary for an effective monitoring program.

- Robert J. Hart, John Rihs (NPS), Howard E. Taylor, and Stephen A. Monroe

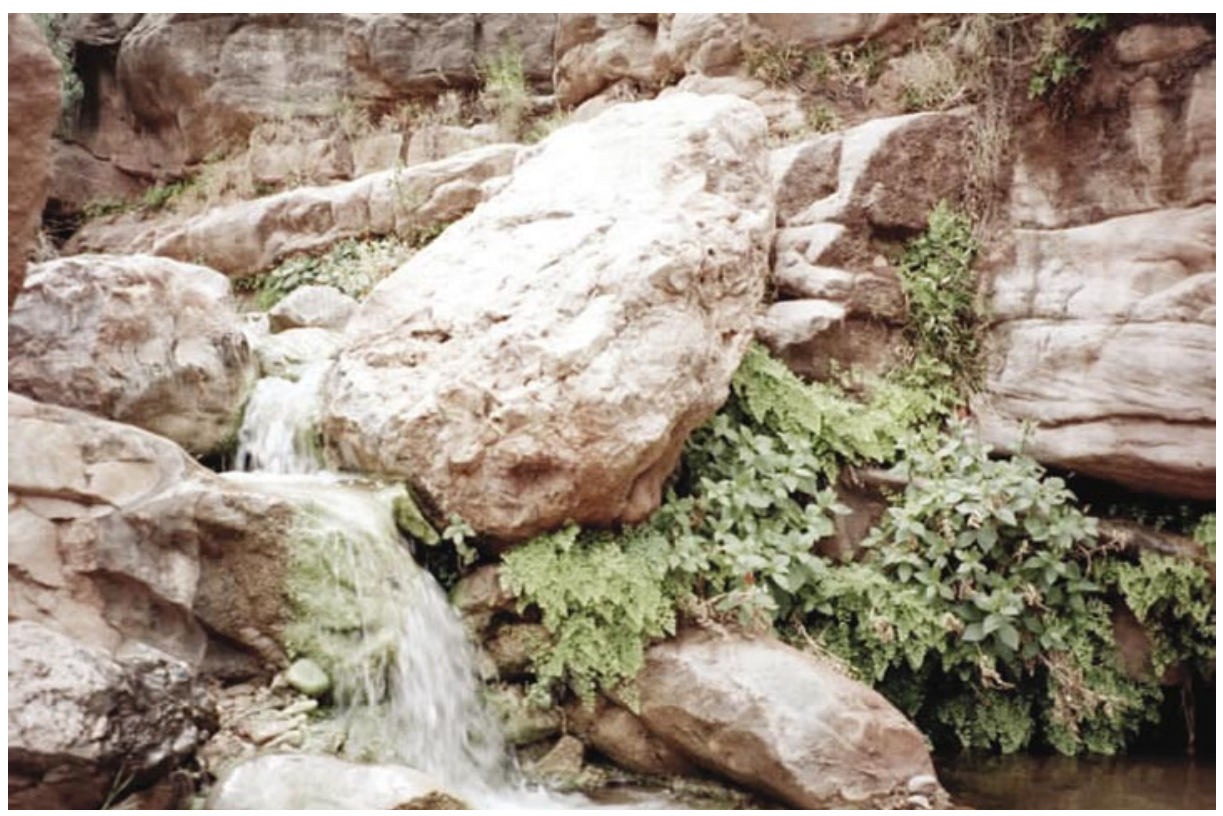

Boucher Spring downstream from source, first major canyon to the west of Hermit Creek

\section{References}

Clean Water Action Plan, 2000, accessed February 1, 2002, at URL

http://www.cleanwater.gov/news/ fact_sheet.html/

Drever, J.I., 1988, The geochemistry of natural waters: Englewood Cliffs, New Jersey, Prentice-Hall Publishers, 437 p.

Fritz, P., and Jean-Charles Fontes, 1980, Handbook of environmental isotope geochemistry, v. 1-2: Amsterdam, Elsevier Scientific Publishing Company, 557 p.

Huntoon, P.W., 1974, The karstic groundwater basin of the Kaibab Plateau, Arizona: Washington, D.C., American Geophysical Union, Water Resources Research, v. 10, no. 3, p. 579-590.

Johnson, P.W., and Sanderson, R.B., 1968, Spring flow into the Colorado River Lees Ferry to Lake Mead, Arizona, Water-Resources Report number 34, Arizona State Land Department, $26 \mathrm{p}$.

Lopes, T.J., and Hoffmann, J.P., 1997, Geochemical analyses of groundwater ages, recharge rates, and hydraulic conductivity of the $\mathrm{N}$ aquifer, Black Mesa Area, Arizona, U.S. Geological Survey WaterResources Investigations Report 96-4190, 42 p.

Metzger, D.G., 1961, Geology in relation to availability of water along the south rim Grand Canyon National Park, Arizona: U.S. Geological Survey Water-Supply Paper 1475 - C, 138 p.

Sellers, W.D., Hill, R. H., and SandersonRae, M., 1986, Arizona Climate, The First Hundred Years. Tucson: University of Arizona Department of Atmospheric Sciences, 80 p.
For further information, contact: Robert J. Hart U.S. Geological Survey, WRD 2255 North Gemini Drive Flagstaff, Arizona 86001

E-mail: bhart@usgs.gov or visit home page http://az.water.usgs.gov GCNP website: www.nps.gov/grca/water 